\title{
PELATIHAN BERBASIS TEKNOLOGI INFORMASI UNTUK MEMBANGUN APLIKASI MOBIL
}

\author{
Edwar Ali ${ }^{*}$, Triyani Arita Fitri ${ }^{2}$, Koko Harianto ${ }^{3}$, Hamdani ${ }^{4}$ \\ STMIK Amik Riau, Pekanbaru, Indonesia \\ *Penulis Koresponsensi, email: edwarali@sar.ac.id
}

Received:15/01/2021

Revised:28/01/2021

Accepted:16/01/2021

\begin{abstract}
SMK N 6 Pekanbaru is one of the vocational schools located in remote areas of Pekanbaru City. In this school there is a Software Engineering (RPL) major that has XII grade students, more than 30 people. The service carried out at this school aims to equip students with technical knowledge of building mobile based application programs. The theme of this service does not overlap with the learning material they get at school. The number of participants is limited to 19 people. The location of the service was carried out at the computer laboratory of SMK $N 6$ Pekanbaru. The executor of this community service consists of 4 lecturers from STMIK Amik Riau who are accompanied by 2 senior students. The duration of implementation is 2 days. After the implementation of the community service activities, students are expected to have an understanding of the technical aspects of building mobile applications to be able to make applications simply.
\end{abstract}

Keywords: technical, applications, mobile

\begin{abstract}
Abstrak. SMK N 6 Pekanbaru merupakan salah satu sekolah kejuruan yang berlokasi di daerah pinggiran Kota Pekanbaru. Pada sekolah ini terdapat jurusan Rekayasa Perangkat Lunak (RPL) yang memiliki siswa kelas XII lebih dari 30 orang. Pengabdian yang dilaksanakan di sekolah ini bertujuan untuk membekali siswa dengan pengetahuan tentang teknis membangun aplikasi program berbasis mobile. Tema pengabdian ini tidak mengalami tumpang tindih dengan materi pembelajaran yang mereka dapatkan di sekolah. Jumlah peserta dibatasi sebanyak 19 orang. Lokasi pengabdian dilaksanakan pada laboratorium komputer SMK N 6 Pekanbaru. Pelaksana kegiatan pengabdian ini terdiri atas 4 orang dosen STMIK Amik Riau yang didamping 2 orang mahasiswa senior. Durasi waktu pelaksanaan adalah selama 2 hari. Setelah dilaksanakannya kegiatan pengabdian ini diharapkan para siswa telah memiliki pemahaman tentang teknis membangun aplikasi mobile hingga dapat membuat aplikasi secara sederhana.
\end{abstract}

Kata Kunci: teknis, aplikasi, mobile

How to Cite: Ali, E., Fitri, T. A. ., Harianto, K., \& Hamdani, H. (2021). PELATIHAN BERBASIS TEKNOLOGI INFORMASI UNTUK MEMBANGUN APLIKASI MOBIL. Mitra Mahajana: Jurnal Pengabdian Masyarakat, 2(1), 31-40.

https://doi.org/10.37478/mahajana.v2i1.790

\section{PENDAHULUAN}

Teknologi Informasi dan Komunikasi (TIK) sebagai bagian dari ilmu pengetahuan dan teknologi secara umum adalah semua teknologi yang berhubungan dengan pengambilan (capturing), pengumpulan (gathering), pengolahan (processing), penyimpanan (storage), penyebaran (dissemination), dan penyajian informasi (reporting). Jika dilihat pada saat sekarang ini, perkembangan teknologi informasi terutama di Indonesia semakin berkembang dengan pergerakan yang sangat cepat. Dengan adanya teknologi informasi dan komunikasi dapat memudahkan orang untuk belajar dan mendapatkan informasi yang dibutuhkan dari mana saja, kapan saja, dan dari siapa saja. Dalam dunia pendidikan pada berbagai jenjang, perkembangan teknologi informasi mulai dirasa mempunyai dampak positifnya karena dengan berkembangnya teknologi informasi dunia pendidikan mulai memperlihatkan perubahan yang sangat berarti(Widjaja, 2010).

Banyak hal yang dirasakan berbeda dan berubah dibandingkan dengan cara pembelajaran yang berkembang era sebelumnya. Saat sekarang ini jarak dan waktu bukanlah sebagai masalah yang berarti untuk mendapatkan ilmu pengetahuan.Beragam aplikasi program tercipta untuk memfasilitasinya. Di Indonesia yang pada dasarnya sebagai negara berkembang di mana 
ketersediaan infrastruktur komunikasi yang masih minim mengakibatkan kesempatan setiap orang untuk mendapatkan informasi dan pengetahuan menjadi terbatas. Ketersediaan infrastruktur ini sangat terasa di daerah-daerah yang upaya untuk memperoleh informasinya masih terbatas(Buchori \& Susanto, 2012). Hal ini disebabkan karena di Indonesia penyebaran teknologi infomasi dan komunikasi masih belum merata. Sekarang ini, hanya di kota-kota besar sajalah yang sudah dengan mudah menikmati dan memanfaatkan fasilitas yang tersedia. Dengan demikian perkembangan pendidikan pun menjadi terhambat dan juga tidak merata.

Salah satu wadah yang dirasa paling berperan dalam dunia teknologi informasi dan komunikasi di Indonesia saat ini adalah peranan internet. Beragam informasi melalui media internet, dapat menjadi salah satu kunci untuk membuat dunia pendidikan di Indonesia mempunyai standar yang sama dengan negara lain. Dengan menggunakan media internet, pemerintah dan institusi pendidikan sudah mulai menerapkan pola belajar yang cukup efektif untuk diterapkan bagi masyarakat yang memiliki kendala dengan jarak dan waktu untuk mendapatkan informasi terutama informasi dalam dunia pendidikan(Rahardjo, Degeng, \& Soepriyanto, 2019), (Towalo, Lumenta, \& Karouw, 2015).

SMK N 6 Pekanbaru merupakan salah satu sekolah kejuruan yang berlokasi di daerah pinggiran Kota Pekanbaru. Tepatnya, sekolah ini berada di Jalan Seroja, Kulim, Kec. Tenayan Raya, Kota Pekanbaru. Sekolah ini berdiri pada tahun 2007 berdasarkan SK No. 91.b Tahun 2007, tertanggal 09-05-2007. Sekolah berstatus negeri ini telah mencapai sejumlah prestasi, salah satunya adalah telah meraih peringkat akreditasi dengan nilai A. Sekolah ini berjarak 15 km dari pusat Kota Pekanbaru. Keberadaan sekolah ini membuka peluang bagi masyarakat sekitarnya, sehingga siswa sekolah ini bukan hanya berasal dari Kota Pekanbaru, tetapi juga dapat menerima siswa yang berdomisili di daerah Kabupaten Pelalawan.

Berdasarkan survei pendahuluan yang dilakukan tim dosen, telah berhasil diidentifikasi tentang konten materi yang mereka butuhkan disampaikan pada kegiatan pengabdian masyarakat. Akhirnya dicapai suatu kesepakatan bahwa perlu adanya pembekalan keahlian bagi para siswa tentang teknis pengembangan aplikasi berbasis mobile. Dengan demikian, maka tim sudah dapat melanjutkan ke dalam bentuk penyusunan proposal kegiatan untuk didanai oleh Lembaga Penelitian dan Pengabdian Masyarakat (LPPM) STMIK Amik Riau.

Kegiatan tersebut digagas oleh dosen STMIK Amik Riau dari lintas program studi sebagai wujud pelaksanaan tri dharma perguruan tinggi yang merupakan kewajiban yang melekat pada setiap pribadi dosen. STMIK Amik Riau merupakan perguruan tinggi ilmu komputer pertama di Provinsi Riau. Lokasi kampusnya berada di Jalan Purwodadi Indah km. 10 Panam Pekanbaru.

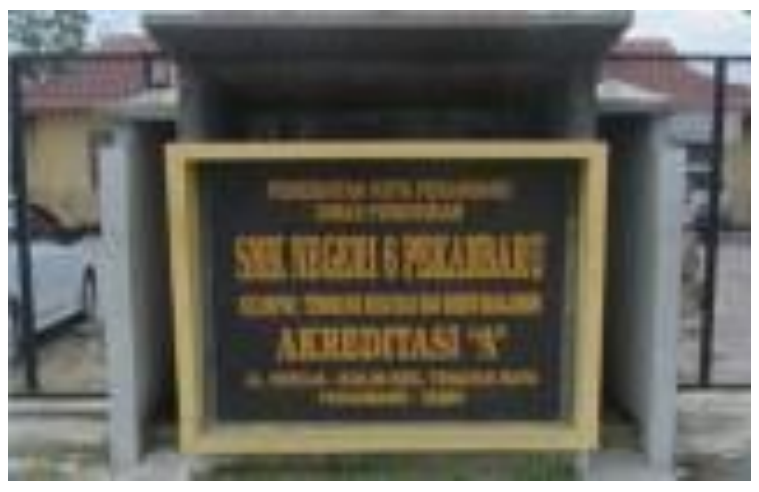

Gambar 1. Gerbang depan SMK N 6 Pekanbaru

Tim pengabdian masyarakat STMIK Amik Riau memandang perlu untuk melakukan kegiatan pengabdian di sekolah ini dengan alasan bahwa di era Revolusi Industri 4.0, para kaum pembelajar milenial harus memiliki kemampuan untuk mengembangkan aplikasi (pemrograman) mobile dan kontennya. Hal ini akan menjadi modal dasar bagi mereka untuk 
berkiprah pada era ini dan dapat mendatangkan manfaat bagi kehidupan mereka di masa depan. Tim pengabdian masyarakat ini terdiri atas 4 (empat) orang dosen STMIK Amik Riau.

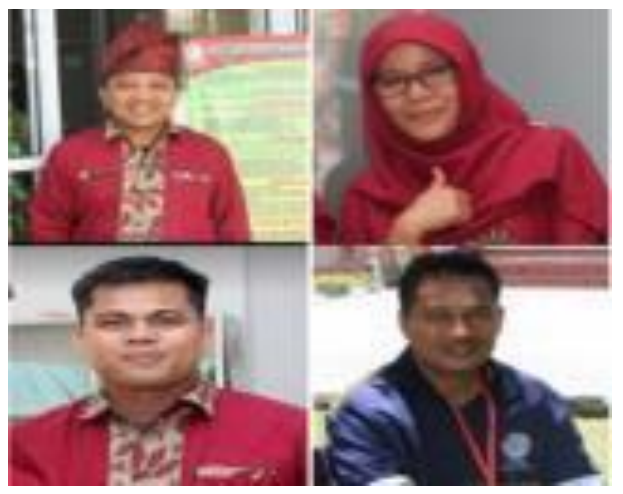

Gambar 2. Tim dosen pelaksana pengabdian masyarakat

Selain itu tim tersebut dibantu oleh 2 (dua) orang mahasiswa. Adapun latar belakang tim ini adalah dari Program Studi (Prodi) Teknologi Informasi dan Teknik Informatika.

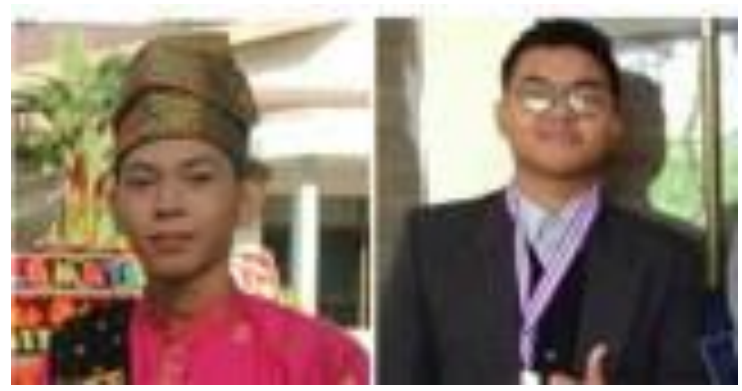

Gambar 3. Tim pengabdian masyarakat dari mahasiswa

Kegiatan pembelajaran pemrograman dasar adalah suatu bentuk usaha untuk memfasilitasi, mendorong dan mendukung pengguna dalam belajar pemrograman. Namun banyak pembelajar khususnya para pemula tidak memiliki pengetahuan dasar tentang pemrograman sehingga mereka menganggap pemrograman merupakan pelajaran yang sulit. Pandangan ini membuat mereka enggan untuk belajar teknis pemrograman(Afrizal Subhan, 2017). Sehingga dibutuhkanlah strategi pembelajaran pemrograman dasar. Konteks pembelajaran yang dimaksudkan di sini teknis pemrograman berbasis mobile phone yang terdiri dari materi dan simulasi soal. Hal ini diperlukan agar dapat memudahkan dan meningkatkan minat pengguna dalam memahami pemrograman. Materi yang diberikan ini akan menyajikan hal mengenai konsep dasar, percabangan, perulangan, array dan terdapat simulasi soal pada setiap materi serta terdapat evaluasi soal. Dengan tersedianya materi ini dan didukung dengan kegiatan pelatihan maka diharapkan agar dapat membantu membantu siswa SMK N 6 Pekanbaru dalam memahami konsep pemrograman mobile.

\section{METODE PELAKSANAAN}

Kegiatan pengabdian masyarakat yang dilakukan oleh tim dari STMIK Amik Riau telah dilakukan dengan mekanisme formal maupun non-formal. Berbagai pendekatan dilakukan agar kedua belah pihak (Tim Pengabdi dan SMK N 6 Pekanbaru). Secara terurut, berikut ini adalah mekanisme formal yang telah ditempuh demi terlaksananya kegiatan pengabdian ini: 


\section{Survei Awal}

Tim pengabdi melakukan kegiatan survei awal dengan cara mengunjungi sekolah SMKN 6 Pekanbaru dengan cara mengirim 2 (dua) orang personil sebagai utusan. Aktifitas ini penting dilakukan untuk mendalami:

a. Ruangan Pelaksanaan Kegiatan

Melalui proses kunjungan langsung, utusan tim melihat lokasi sekolah dan tempat pelaksanaan kegiatan pengabdian. Selanjutnya dilakukan pendalaman terkait dengan status ruangan yang akan digunakan, hingga dicapai kesepatan bahwa kegiatan tersebut dapat dilaksanakan di laboratorium komputer SMK N 6 Pekanbaru. Pada hari yang ditetapkan tidak ada kegiatan lain dilaksanakan pada ruangan tersebut dan siswa juga tidak memiliki agenda lain. Bentuk ruangan yang akan digunakan dapat dilihat pada Gambar 4 berikut ini.

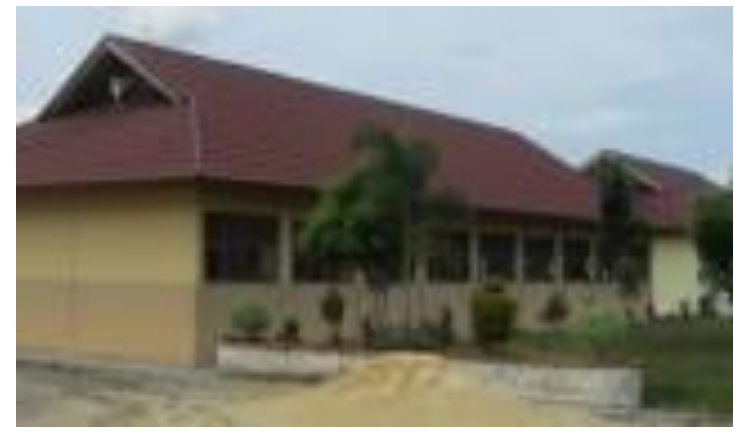

Gambar 4. Gedung Laboratorium Komputer

Bangunan ini masih relatif baru dan telah beroperasi selama 5 (lima) bulan. Sebelumnya kegiatan praktikum siswa menggunakan ruangan kelas yang disulap menjadi laboratorium komputer. Laboratorium ini memiliki kapasitas 20 tempat duduk di mana masing-masingnya terdapat meja kerja tersendiri.

b. Kondisi peralatan yang digunakan

Berdasarkan pantauan langsung, terdapat 20 unit komputer yang siap untuk digunakan. Sistem operasi yang digunakan adalah MS-Windows 10 dengan kapasitas RAM 8GB. Kondisi ini sangat ideal untuk digunakan dalam membuat program aplikasi mobile.

c. Kandidat Peserta

Kandidat peserta berasal dari siswa kelas XII. Mengingat keterbatasan jumlah komputer dan daya tampung ruangan, maka dicapai kesepakatan untuk dilakukan seleksi oleh pihak SMKN 6 Pekanbaru. Seleksi tersebut berakhir dengan keputusan mengikut sertakan 19 orang siswa, dengan catatan bagi yang tidak mendapat jatah penggunaan PC agar membawa laptop masing-masing.

d. Baseline pengetahuan kandidat peserta.

Aktifitas ini penting dilakukan agar tim pengabdian dapat menempuh jalur yang tepat untuk mentransfer pengetahuan. Berdasarkan pengamatan tersebut, mayoritas siswa belum pernah mempelajari pembuatan aplikasi pemrograman berbasis mobile.

\section{Proses Administrasi dan Komunikasi}

Tim pengabdi selanjutnya menyusun proposal kegiatan pengabdian untuk diajukan ke Lembaga Penelitian dan Pengabdian Masyarakat (LPPM) STMIK Amik Riau. Proposal tersebut direview oleh tim dosen yang ditunjuk LPPM. Bagi proposal yang dinyatakan lulus seleksi maka dilanjutkan ke proses penandatanganan kontrak kerja antar tim pengabdian dengan pihak LPPM. Dengan demikian, selanjutnya tim pengabdian mengirimkan surat pemberitahuan 
pelaksanaan kegiatan pengabdian kepada pihak SMK N 6 Pekanbaru. Pihak sekolah memberikan konfirmasi terkait kesiapan jadwal, waktu dan tempat kegiatan hingga jumlah peserta yang akan dilibatkan.

\section{Persiapan Lokasi}

Kegiatan ini dilakukan oleh pihak laboratorium komputer SMK N 6 Pekanbaru atas instruksi dari Kepala Sekolah. Segala perangkat keras dan lunak yang diperlukan untuk kegiatan pengabdian dipersiapkan sambil terus berkoordinasi dengan tim pengabdian STMIK Amik Riau.

\section{Persiapan Materi Pengabdian}

Di sisi lain, tim pengabdian melakukan persiapan berupa pembuatan baliho, materi pelatihan, cinderamata, dan konsumsi kegiatan. Fokus dari tahapan ini adalah mengembangkan materi pelatihan dalam bentuk digital. Ketua tim telah memberikan cakupan materi dan penanggung jawab masing-masing materi serta membuat sendiri slide dalam format MSPowerpoint.

\section{Koordinasi Tim}

Tim pengabdian melakukan rapat pembahasan tentang teknis pelaksanaan kegiatan. Selain itu juga melakukan pemeriksaan segala persiapan seperti: baliho, alat transportasi, konsumsi, materi, cinderamata, dan sebagainya. Hal ini bertujuan untuk menjamin bahwa kegiatan pengabdian dapat berjalan sesuai dengan rencana. Pembagian tugas/peran sangat jelas sehingga setiap orang telah mengenali secara baik tentang kegiatan apa yang akan dilakukan dan berperan sebagai sosok tertentu.

\section{Pelaksanaan Kegiatan}

Pelaksanaan kegiatan dibuka secara langsung oleh Kepala Sekolah SMK N 6 Pekanbaru dengan didampingi oleh beberapa orang guru dan tenaga kependidikan. Dosen pelakana melaksanakan kegiatan dengan didampingi oleh 2 orang mahasiswa. Dosen akan memberikan pemaparan dan contoh tahapan kegiatan pemrograman. Apabila peserta mengalami kendala maka segera diatasi oleh mahasiswa yang mendampingi.

Kegiatan ditutup pada hari kedua oleh Wakil Kepala Sekolah Bidang Kurikulum. Selanjutnya kegiatan dilanjutkan dengan dokumentasi (foto bersama).

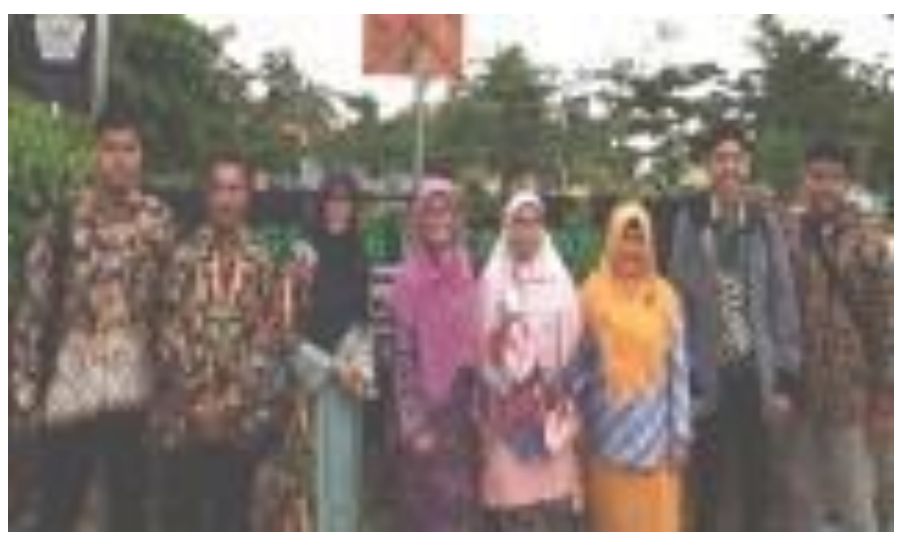

Gambar 5. Foto bersama tim bersama pihak sekolah

Pada saat penutupan kegiatan, pihak sekolah terus memberikan ruang bagi pihak STMIK Amik Riau untuk terus mengabdikan ilmunya di SMK N 6 Pekanbaru. Lebih jauh hal tersebut dapat ditindaklanjuti dalam bentuk kerjasama. Hal ini sangat bermanfaat bagi kedua belah pihak. Pada sisi pandang siswa peserta pelatihan dapat memunculkan minat dan motivasi untuk mengeksplorasi lebih jauh tentang keilmuan pemrograman. 
Acara dilanjutkan dengan bertukar cinderamata dan bersalam-salaman. Tim dosen pengabdi dapat terus memberikan semangat kepada para siswa peserta untuk terus mengembangkan diri dan STMIK Amik Riau sangat terbuka untuk menerima kedatangan mereka yang ingin belajar. Para siswa peserta terlihat antusias memperhatikan wejangan dari dosen pengabdi, terlebih lagi rata-rata guru mereka adalah alumni dari STMIK Amik Riau. Berikut ini pada Gambar 6 adalah suasana foto bersama antara tim pengabdi, pihak sekolah, dan para siswa peserta pelatihan.

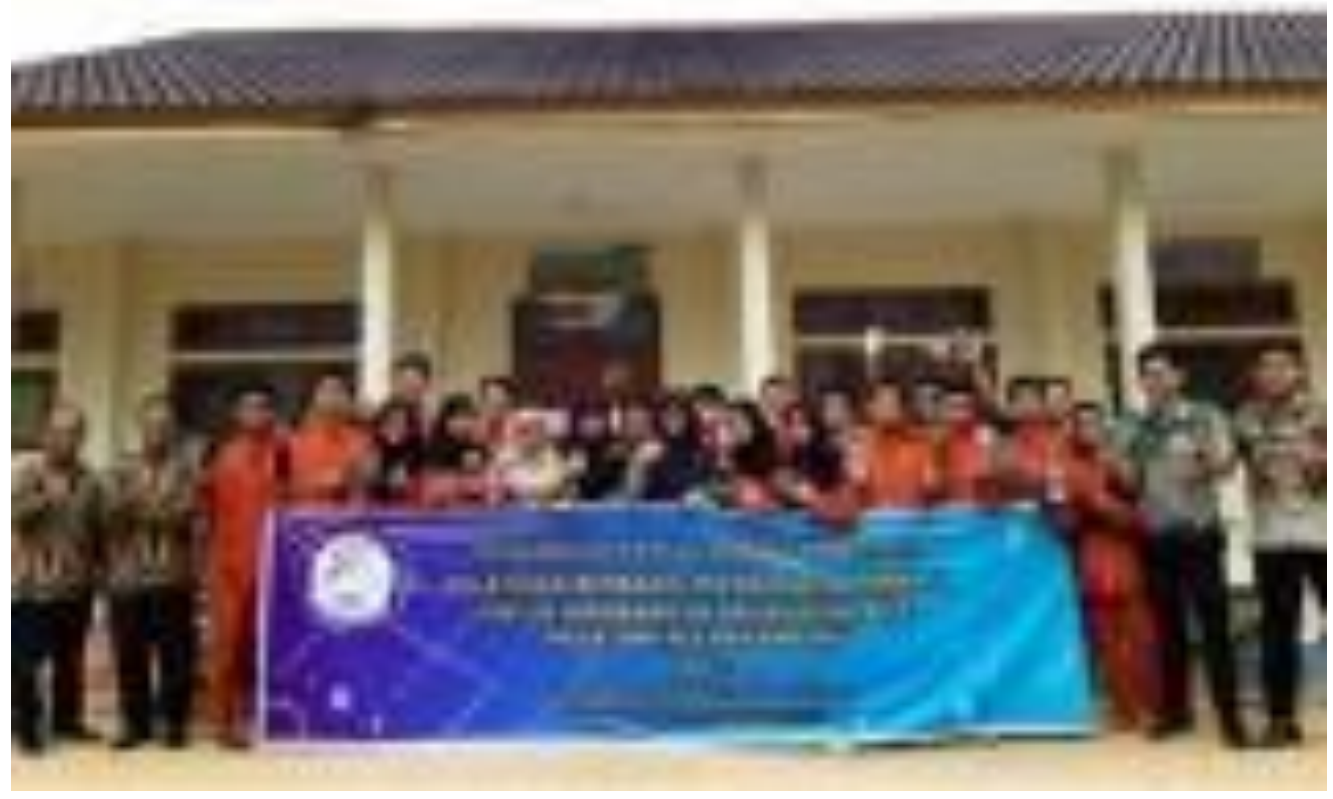

Gambar 6. Foto bersama peserta pelatihan

Pada akhir kegiatan pengabdian dilakukan evaluasi terhadap para peserta yang berjumlah 19 orang. Sebanyak 15 orang mampu menyelesaikan tugas dengan baik sesuai harapan, sedangkan yang lainnya butuh waktu lebih lama untuk melakukannya.

\section{Evaluasi Hasil Kegiatan}

Setelah kegiatan dilakukan dilakukan evaluasi 2 arah, yaitu : 1 . Tim pengabdi memberikan penugasan terhadap seluruh siswa peserta pelatihan, 2. Angket penilaian atas kegiatan pengabdian masyarakat di SMK 6 Pekanbaru. Selanjutnya di tingkat institusi terdapat pembahasan terkait hasil yang telah dicapai dalam kegiatan pengabdian, termasuk hal-hal teknis yang perlu perbaikan di masa yang akan datang.

\section{Pelaporan dan Publikasi}

Seluruh kegiatan pengabdian yang dilakukan, sesuai kontrak yang tertera pada dokumen bahwa setiap tim diwajibkan untuk membuat dokumentasi kegiatan (foto dan video), menyusun laporan kegiatan, membuat poster kegiatan, dan mempublikasikan kegiatan pada jurnal pengabdian masyarakat. Keseluruhan hal yang dinyatakan di atas telah tertera dalam kerangka acuan pada dokumen kontrak kegiatan pengabdian masyarakat dan selanjutnya diserahkan kepada LPPM STMIK Amik Riau)

\section{HASIL DAN PEMBAHASAN}

Kegiatan pengabdian kepada masyarakat yang telah dilakukan oleh tim yang terdiri dari dosen dan mahasiswa STMIK Amik Riau berlangsung dari tanggal 20-21 November 2019. Adapun dosen dan mahasiswa yang terlibat dalam kegiatan ini adalah seperti yang tercantum dalam Tabel 1 berikut ini. 
Edwar Ali, Triyani Arita Fitri, Koko Harianto, Hamdani

Mitra Mahajana: Jurnal Pengabdian Masyarakat 2(1), 2021, 31-40

Tabel 1. Tim pengabdian masyarakat

\begin{tabular}{cllll}
\hline No. & \multicolumn{1}{c}{ Nama Dosen } & Status & Jabatan & Prodi \\
\hline 1 & Edwar Ali, M.Kom & Dosen & Ketua & Teknologi Informasi \\
\hline 2 & Triyani Arita Fitri, M.Kom & Dosen & Anggota & Teknik Informatika \\
\hline 3 & Koko Harianto, M.Kom & Dosen & Anggota & Teknologi Informasi \\
\hline 4 & Hamdani, M.Kom & Dosen & Anggota & Teknologi Informasi \\
\hline 5 & M. Amin Rahman & Mahasiswa & Anggota & Teknologi Informasi \\
\hline 6 & Kurnia Sandi & Mahasiswa & Anggota & Teknik Informatika \\
\hline
\end{tabular}

Adapun kegiatan ini didanai langsung melalui mekanisme kompetitif di lingkungan STMIK Amik Riau di bawah koordinasi Lembaga Penelitian dan Pengabdian Masyarakat (LPPM) STMIK Amik Riau. Normalnya LPPM mendanai 5 proposal terbaik setiap semester. Apabila sebuah proposal dinyatakan lulus tahap penilaian kelayakan oleh reviewer, maka akan dilanjutkan dengan proses penandatanganan kontrak (No. 02/Kontrak/LPPM-STMIK Amik Riau/IX/2019) yang disertai dengan surat pengantar (No. 02/Abdimas-2/IX/2019) ke objek pengabdian (SMK N 6 Pekanbaru). LPPM memberikan tenggat waktu pelaksanaan pengabdian masyarakat tersebut, sehingga tim lebih leluasa untuk membuat kesepakatan waktu dan tempat pelaksanaan tengan objek pengabdian.

Kegiatan pengabdian masyarakat selanjutnya disepakati antara tim dengan pihak SMK N 6 Pekanbaru, yaitu pada tanggal 20-21 November 2019. Adapun tempatnya adalah Laboratorium Komputer SMK N 6 Pekanbaru. Pelaksanaan kegiatan tim ini selanjutnya didukung oleh surat tugas yang diterbitkan oleh LPPM STMIK Amik Riau (No. 96/C-01/STMIK Amik Riau/XI/2019 tertanggal 09 November 2019).

Hal-hal yang dipersiapkan antara lain: 1 unit spanduk kegiatan, 1 paket materi dalam format digital, Android Studio, konsumsi, cinderamata, dan transportasi. Pihak sekolah mempersiapkan PC (Personal Computer) untuk membuat program. Sedangkan masing-masing peserta diminta untuk membawa smartphone. Sebelum kegiatan dilaksanakan kembali dilakukan pemeriksaan kondisi terkait kesiapan lokasi/tempat serta peralatan. Koordinasi terus dilakukan dengan pihak manajemen laboratorium SMK N 6 Pekanbaru. Salah satu hal yang menguntungkan adalah adanya guru TIK di sekolah tersebut yang merupakan alumni STMIK Amik Riau.

Pada saat kegiatan pengabdian dilakukan, secara bergantian dosen memaparkan dan menjelaskan teknis pemrograman. Siswa peserta mengikuti arahan dari instruktur di depan dan mendapatkan bantuan teknis dari dosen dan mahasiswa yang berada dekat mereka. Momen tersebut dapat dilihat pada Gambar 7.

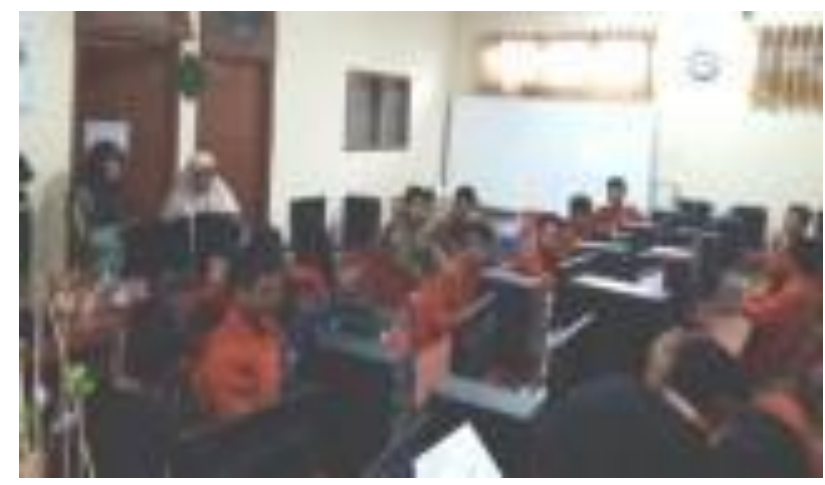

Gambar 7. Suasana kegiatan pengabdian

Pada hari pertama (Rabu tanggal 20 November 2019) sesi diawali dengan penjelasan tentang ragam aplikasi mobile yang ada disekitar mereka (para peserta). Secara sporadis 
ditanamkan dalam mindset mereka bahwa memprogram itu mudah asal tahu kiat dan alur fikirnya. Selanjutnya dijelaskan perlengkapan yang diperlukan dan bagaimana memulai membuat aplikasi program. Berikutnya pada hari kedua (Kamis tanggal 21 November 2019), mereka langsung mempraktekkan pembuatan program di bawah arahan tim pengabdi yang didampingi mahasiswa.

Salah satu hal yang menarik bahwa untuk melaksanakan pembelajaran, terutama pemrograman sangat diperlukan upaya awal membangkitkan gairah dan minat mereka. Pola fikir sebagai pengguna secara perlahan diubah untuk menjadi seorang kreator(Afrizal Subhan, 2017). Terbukti selama kegiatan tersebut tidak ada peserta yang meninggalkan ruangan selama sesi berjalan karena mereka merasakan hal yang penting untuk mereka kuasai. Terlebih lagi terlihat mereka sangat nyaman dengan materi yang diberikan dan jarang terjadi keluhan karena mengalami kendala dalam mengerjakan program aplikasinya.

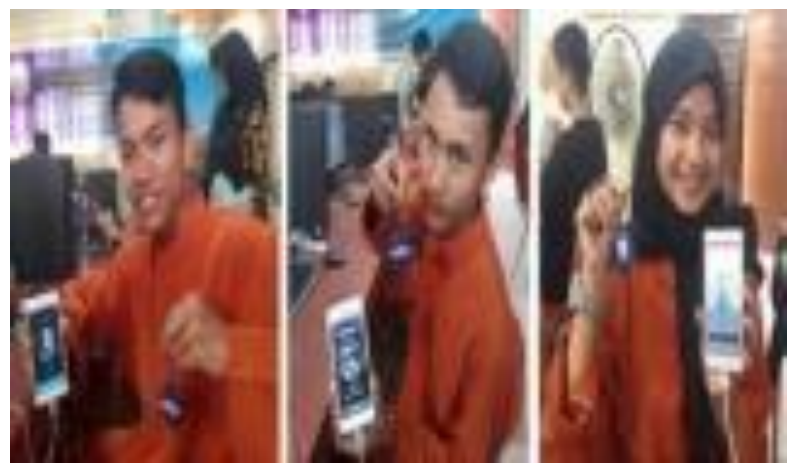

Gambar 8. Sikap antusias peserta pelatihan

Setelah pelatihan dilakukan dilanjutkan dengan aktivitas evaluasi dengan cara memberikan contoh kasus. Aktivitas ini penting untuk dilakukan untuk mengetahui tingkat keberhasilan pada dua sisi: (1) Tim Pengabdian Masyarakat. Hal ini menjadi tolok ukur bagi tim untuk menilai keberhasilan materi dan strategi transfer pengetahuan yang dilakukan. Segala hal yang dianggap baik akan terus ditingkatkan dan apabila ada kelemahan, maka akan dilakuan evaluasi dalam rangka perbaikan ke depannya, dan (2) Peserta Pelatihan. Melalui evaluasi yang dilakukan terhadap pada peserta, maka tim pengabdian dapat mengetahui tingkat pemahaman dan daya serap para peserta terhadap materi yang diberikan.

Evaluasi terhadap para peserta ditempuh melalui pemberian kasus berupa pengembangan dari materi yang diberikan. Peserta diberikan waktu selama 30 menit untuk menyelesaikan kasus yang diberikan. Hasil yang dicapai sangat menggembirakan, di mana dari 19 orang peserta terdapat sebanyak 15 orang berhasil menyelesaikan tepat waktu dan benar (baik) dan selebihnya memerlukan waktu tambahan. Hal tersebut seperti ditunjukkan pada grafik berikut ini.

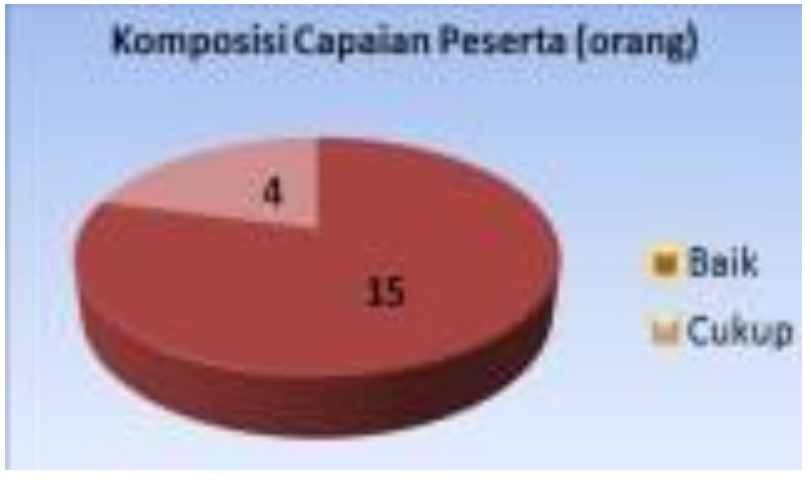

Gambar 9. Komposisi hasil evaluasi kegiatan 
Hasil yang dicapai dengan kondisi seperti Gambar 9 adalah sebagai indikasi bahwa para peserta sangat memahami materi pelatihan yang disampaikan oleh tim pengabdian masyarakat. Klain keberhasilan kegiatan tidak dapat dinyatakan begitu saya dengan melihat suasan permukaan saja. Perlu ada instrument untuk membuktikannya. Tim menggunakan instrument berupa angket yang dibuat sedemikian rupa sehingga dapat diisi secara online oleh peserta. Saat menjelang penutupan kegiatan pengabdian masyarakat, tim menyebarkan angket yang dapat diisi secara online (Google Form) oleh seluruh peserta. Pada angket tersebut telah diajukan sebanyak 10 pertanyaan singkat yang dapat diisi oleh para peserta pelatihan dengan menggunakan smartphone mereka masing-masing. Sebanyak 19 orang peserta, terdapat 17 orang yang sukses mengisi angket penilaian. Hasilnya seperti terlihat dapat grafik berikut ini.

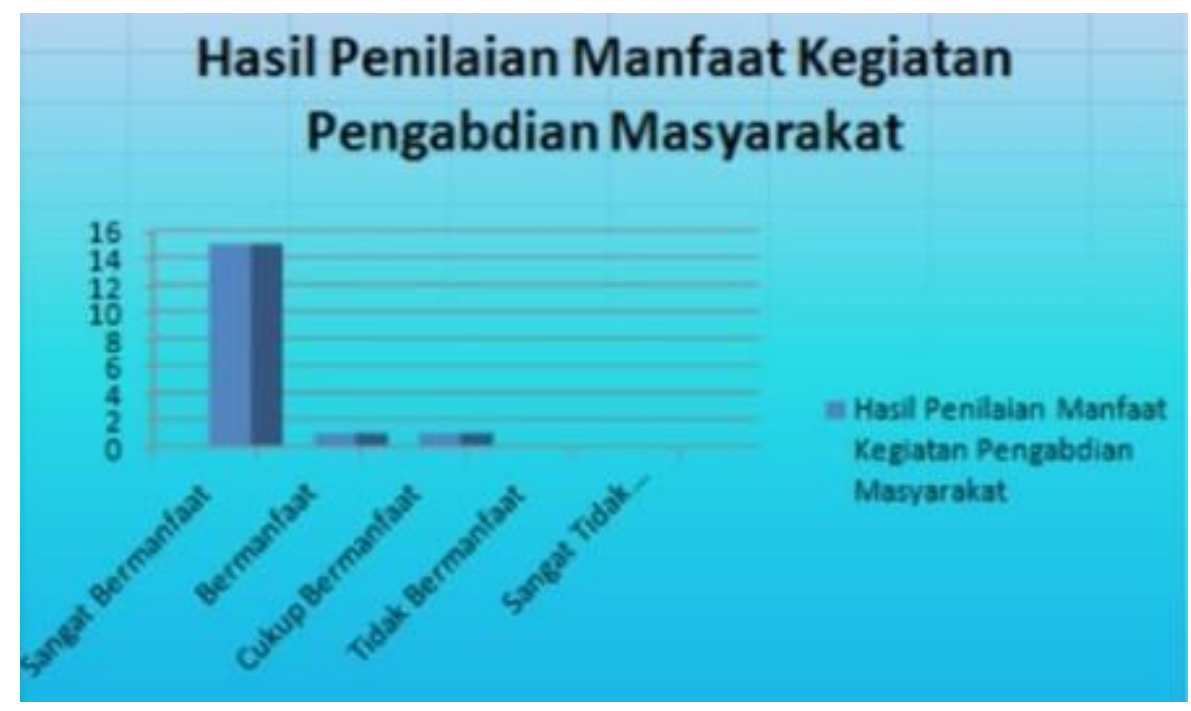

Gambar 10. Hasil penilaian peserta terhadap kinerja tim

Gambar 10 menunjukkan bahwa dari 17 orang peserta yang menjawab angket penilaian, diperoleh hasil akhir bahwa: sebanyak 15 orang peserta menyatakan bahwa kegiatan pelatihan tersebut sangat bermanfaat. Sebanyak 1 orang yang menyatakan bermanfaat, dan 1 orang lainnya menyatakan cukup bermanfaat. Tidak ada peserta yang memberikan penilaian negatif. Dua orang peserta yang tidak memberikan jawaban ternyata mengalami gangguan teknis dengan smartphone-nya saat melakukan koneksi itnternet.

Secara keseluruhan, maka dapat dinyatakan bahwa kegiatan pengabdian masyarakat ini memiliki makna yang sangat berarti dan menguntungkan ke dua belah pihak secara mutualisme. Pada sisi dosen, kegiatan pengabdian masyarakat merupakan kewajiban dosen dalam melaksanakan tri dharma perguruan tinggi. Sedangkan di sisi peserta sebagai objek kegiatan, akan meningkatkan motivasi para siswa SMK N 6 Pekanbaru, Jurusan Rekayasa Perangkat Lunak (RPL) untuk mengeksplorasi lebih jauh tentang teknologi perangkat lunak, khususnya pemrograman.

\section{SIMPULAN DAN TINDAK LANJUT}

Berdasarkan kegiatan pengabdian masyarakat yang telah dilaksanakan pada SMK N 6 Pekanbaru, terdapat beberapa hal yang dapat dipetik dan dijadikan sebagai kesimpulan, antara lain:

1. Kegiatan pengabdian merupakan unsur kewajiban yang melekat pada setiap dosen dan setiap kegiatan mesti terlihat dampak jangka pendek dan jangka panjang pada objek pengabdian. 
2. Upaya yang terpenting dilakukan untuk membekali para siswa dengan kemampuan memprogram berawal dari usaha untuk membangkitkan minat mereka untuk bersikap dan berperilaku untuk menjadi seorang programmer.

3. Berdasarkan hasil evaluasi yang diberikan pada akhir kegiatan, dari 19 orang peserta aktif terdapat 15 orang siswa mampu menyelesaikan tugas yang diberikan dengan kualitas baik.

4. Perlu adanya upaya dari sekolah untuk membekali para siswanya dengan pembentukan pola fikir tentang bagaimana tahapan dan logika dalam membuat suatu aplikasi program.

5. Teknis pembuatan aplikasi mobile yang disampaikan pada saat kegiatan pengabdian, dapat difahami dan diserap oleh para siswa, hingga mereka mampu membuat aplikasi dengan menggunakan logika dasar.

6. Dinamika yang terjadi dalam perkembangan teknologi informasi harus dicermati selalu agar segala sesuatu yang diajarkan selalu up to date.

Agar rintisan kegiatan pengabdian ini dapat memberikan efek yang nyata terhadap para siswa maka dimasa yang akan datang diperlukan penguatan di bidang pembentukan pola fikir dan logika para siswa sejak menduduki kelas X. Selain itu juga diperlukan pembaharuan terhadap kurikulum pembelajaran yang lebih menantang sesuai dengan perkembangan teknologi informasi dan komunikasi.

Sebagai bentuk lanjut dari kegiatan pengabdian masyarakat ini, maka pada tahap berikutnya akan dilaksanakan program kemitraan dengan cara melakukan seleksi terhadap beberapa siswa yang berpotensi. Selanjutnya, mereka diberikan pelatihan berdurasi 1 (satu) minggu di STMIK Amik Riau. Setelah berakhirnya pelatihan tersebut diharapkan terbentuk komunitas yang secara intensif mempelajari dan mengembangkan aplikasi mobile.

\section{DAFTAR PUSTAKA}

Afrizal Subhan, A. (2017). Rancang Bangun Aplikasi Pembelajaran Dasar Pemrograman Berbasis Mobile Phone. Jurnal Teknik Informatika Politeknik Sekayu (TIPS), 6(1), 4-19.

Buchori, A., \& Susanto, H. A. (2012). PENGEMBANGANMEDIA MOBILE-LEARNING BERBASIS SOFTWARE CLASSPAD CASIO PADAMATA KULIAH GEOMETRI DATAR DI PERGURUAN TINGGI. Edumatica, 02(April), 1-10.

Rahardjo, T., Degeng, N., \& Soepriyanto, Y. (2019). Pengembangan Multimedia Interaktif Mobile Learning Berbasis Anrdroid Aksara Jawa Kelas X Smk Negeri 5 Malang. Jurnal Kajian Teknologi Pendidikan, 2(3), 195-202. https://doi.org/10.17977/um038v2i32019p195

Towalo, D., Lumenta, A., \& Karouw, S. (2015). Perancangan Mobile Learning Algoritma Dan Pemrograman. Jurnal Teknik Informatika, 4(2), 1-5. https://doi.org/10.35793/jti.4.2.2014.6986

Widjaja, H. A. E. (2010). Perencanaan Strategi Sistem Dan Teknologi Informasi Pada PT. Microsis. ComTech: Computer, Mathematics and Engineering Applications, 1(2), 629. https://doi.org/10.21512/comtech.v1i2.2563 